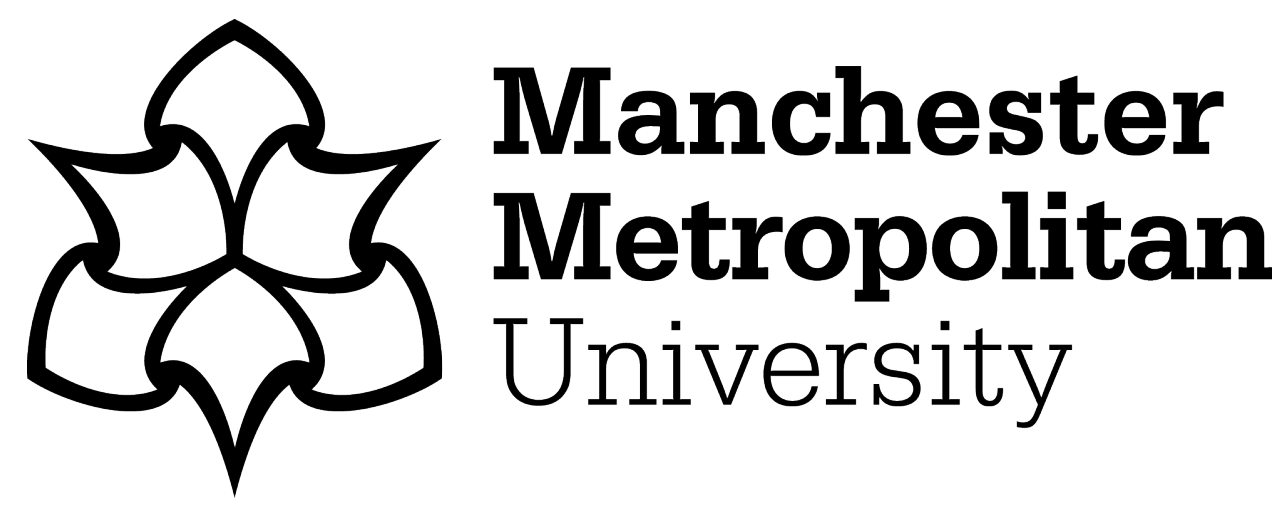

Rampasso, IS, Martins, VWB, Pavan Serafim, M, Cavaliero, CKN, Gonçalvez Quelhas, OL, Leal Filho, W and Anholon, R (2022) Brazilian contributions to the Sustainable Development Goal 7 and policy implications. Kybernetes, 51 (10). pp. 3025-3040. ISSN 0368-492X

Downloaded from: https://e-space.mmu.ac.uk/628426/

Version: Accepted Version

Publisher: Emerald

DOI: https://doi.org/10.1108/K-04-2021-0351

Usage rights: Creative Commons: Attribution-Noncommercial 4.0

Please cite the published version 


\title{
Brazilian contributions to the 7th Sustainable Development Goal of United Nations and policy implications
}

\author{
Rampasso, I.S ${ }^{\mathrm{a}, \mathrm{b}}$; Martins, V.W.B ${ }^{\mathrm{b}, \mathrm{c}}$; Anholon, R ${ }^{\mathrm{b}}$; Cavaliero, C.K.N ${ }^{\mathrm{b}}$; Quelhas, \\ O.L.G ${ }^{\mathrm{a}}$; Leal Filho, $\mathrm{W}^{\mathrm{d} *}$
}

\section{Kybernetes 01 Jan 2021 DOI http://doi.org/10.1108/K-04-2021-0351}

${ }^{a}$ Laboratory of Technology, Business and Environment Management. Federal Fluminense University. Passo da Pátria Street, 156. Niterói, Rio de Janeiro, Brazil.

${ }^{b}$ School of Mechanical Engineering, University of Campinas. Mendeleyev Street, 200. Campinas, São Paulo, Brazil.

${ }^{c}$ Department of Production Engineering, State University of Pará, Travessa Dr. Enéas Pinheiro, 2626. Belém, PA, Brazil.

d Faculty of Life Sciences, Hamburg University of Applied Sciences, Lohbruegger Kirchstraße 65, Sector S4, Hamburg, Germany and Manchester Metropolitan University, UK

*Corresponding author: walter.leal2@haw-hamburg.de

(Rampasso, I.S) izarampasso@gmail.com; (Martins, V.W.B) vitor.martins@uepa.br; (Anholon, R) rosley@fem.unicamp.br; (Cavaliero, C.K.N) cavaliero@fem.unicamp.br; (Quelhas, O.L.G) osvaldoquelhas@id.uff.br; (Leal Filho, W) walter.leal2@haw-hamburg.de

\section{Acknowledgements}

This work was supported by the Conselho Nacional de Desenvolvimento Científico e Tecnológico (CNPq) under Grants 307536/2018-1 and 305442/2018-0; by Coordenação de Aperfeiçoamento de Pessoal de Nível Superior - Brasil (CAPES) - Finance Code 001, under process 88887.464433/2019-00; and by the Universidade do Estado do Pará (UEPA) under Grant 626/18. 


\section{Introduction}

The United Nations (UN), in the general meeting of September 25, 2015, set goals to transform the world by the year 2030, considering actions in 17 macro objectives of sustainable development (Barthélemy et al., 2018; Cernev and Fenner, 2020; JiménezAceituno et al., 2019; UN, 2015). Among these goals, the seventh objective focuses on the adoption of practices that ensure affordable and clean energy for all (Moyer and Bohl, 2019; Munro et al., 2017; Olawuyi, 2020; UN, 2019, 2015). Affordable energy resources play an important role in the consolidation and stability of the world economy, since besides ensuring sustainable growth, they also provide social welfare.

According to Kveselis et al. (2017), sustainable energy development by a nation aims to improve efficiency in all processes from energy supply chain by minimizing extraction, transport and conversion, as well as supply losses from better consumer installations; new technologies can greatly contribute to the achievement of these objectives.

When analysing the global energy matrix, the situation is not favourable. The use of energy resources has increased considerably in recent decades in almost all countries and, in general, this use has been occurring in a disorderly and unplanned manner, especially in nations classified as "developing" (Kveselis et al., 2017). Hayat et al. (2019) stress that sustainable development goals cannot be achieved without a robust planning for the use of sustainable energy. As a consequence of this challenge, planet environmental degradation is intensifying (Barata et al., 2014; Sahabmanesh and Saboohi, 2017). Cozendey da Silva et al. (2018), Filipović et al. (2019) and Basaran et al. (2015) also highlight the relevance of renewable sources of energy for sustainable development for countries.

Focusing on the reality of developing nations, it is important to analyse how Brazil has been acting in pursuit of SDG 7, regarding the achievement of the targets established by UN. Brazil among the 10 largest economies in the world (The World Bank, 2019) and has a considerable and growing consumption of energy. In general, the Brazilian energy system has a diversified matrix, having a focus on hydroelectric generation (de Melo et al., 2016; IEA, 2018). According to Borges et al. (Borges et al., 2018), the energy management is among the most common environmental practice related to Corporate Social Responsibility performed by Brazilian companies. In this sense, Brazil have been recognized as a country with an energy matrix cleaner than many other countries, including developed ones ( $\mathrm{Pao}$ and $\mathrm{Fu}$, 2013; Pischke et al., 2019). In recent years, however, the increasing demand for energy and the lack of prior planning have provided some challenges for the country, such as the need to expand the use of thermoelectric plants for complementary generation in relation to what is needed (Arias-Gaviria et al., 2019; Carstens and Cunha, 2019; Dranka and Ferreira, 2018).

Considering the presented scenario and the lack of research focused on achieving the goals linked to the UN's Seventh Sustainable Development Goal by developing nations (de Oliveira Neto et al., 2019), this research aims to evaluate, in the view of experts, how Brazil has been acting in favour of these activities. That is, is Brazil on the right track to provide affordable, reliable, sustainable and modern energy for all? Or is there still much to be done? It is important to emphasize that this research has an exploratory character and aims to contribute to expand the debates on the subject.

In addition to this introductory section, this article presents four more sections. Section 2 is devoted to the theoretical background regarding Sustainable Development Goals (SDGs) and specifically the seventh objective. Section 3 presents the methodological procedures used, enabling other researchers to replicate the research in other contexts. We understand that all research must be reliable, that is, plausible to replicate. Section 4 presents the results obtained from the study, highlighting the averages attributed by the experts to Brazilian practices to achieve the targets set by the UN for the seventh objective and, subsequently, performing a 
comparative ordering of them. Section 5 presents the conclusions and final considerations and, finally, the references used are listed.

\section{Theoretical Background}

According to Chams and García-Blandón (2019), the SDGs are achieved through efforts to raise awareness of human capital, aiming at the adoption of new techniques and the insertion of innovative sustainable strategies in all economic sectors (Macellari et al., 2018). These efforts aim at human and environmental development (Bebbington and Unerman, 2018; Few et al., 2019).

The SDGs can be understood as a set of universal goals and indicators; they aim to eradicate poverty in all its forms and to provide a sustainable balance between economic, environmental and social aspects (Leal Filho et al., 2019). The 17 sustainable development goals are: "No Poverty"; "Zero Hunger"; "Good Health and Well-being"; "Quality Education"; "Gender Equality"; "Clean Water and Sanitation"; "Affordable and Clean Energy"; "Decent Work and Economic Growth"; "Industry, Innovation and Infrastructure"; "Reduced Inequality"; "Sustainable Cities and Communities"; "Responsible Consumption and Production"; "Climate Action"; "Life Below Water"; "Life on Land"; "Peace, Justice and Strong Institutions"; "Partnerships to achieve the Goals" (UN, 2015).

Focusing specifically on the seventh objective set by the UN, the following targets are to be achieved: 7.1: "By 2030, ensure universal access to affordable, reliable and modern energy services"; 7.1.1: "Proportion of population with access to electricity"; 7.1.2: "Proportion of population with primary reliance on clean fuels and technology"; 7.2: "By 2030, increase substantially the share of renewable energy in the global energy mix"; 7.2.1: "Renewable energy share in the total final energy consumption"; 7.3: "By 2030, double the global rate of improvement in energy efficiency"; 7.3.1: "Energy intensity measured in terms of primary energy and GDP"; 7.A: "By 2030, enhance international cooperation to facilitate access to clean energy research and technology, including renewable energy, energy efficiency and advanced and cleaner fossil-fuel technology, and promote investment in energy infrastructure and clean energy technology"; 7.A.1: "International financial flows to developing countries in support of clean energy research and development and renewable energy production, including in hybrid systems"; 7.B: "By 2030, expand infrastructure and upgrade technology for supplying modern and sustainable energy services for all in developing countries, in particular least developed countries, small island developing States, and land-locked developing countries, in accordance with their respective programmes of support"; 7.B.1: "Investments in energy efficiency as a percentage of GDP and the amount of foreign direct investment in financial transfer for infrastructure and technology to sustainable development services" (UN, 2015).

As previously mentioned, the disseminated SDGs have a global focus, but the development of actions to achieve them depends on actions taken in each country (Salvia et al., 2019) and, for this, it is necessary to consider the specificities of each nation, developed or under development.

In this context and considering the differences between the economic contexts of each country, Jalali et al. (2019) analysed the energy efficiency of 132 countries, categorizing them into similar performance groups using a clustering algorithm. The results indicated that less developed countries have opportunities for energy efficiency improvements, while countries characterized as developed may become more efficient in the field of energy consumption. For the analysed database, the authors highlighted that countries that moved between clusters in the period (2007-2014) were those that improved their indicators associated with renewable energy consumption and energy productivity. Guney (2019) corroborates the above information by highlighting the importance of investments in renewable energy to achieve the 
seventh objective; the author also argues that, for developed and developing countries, there is a positive impact of renewable energy.

Also in the context of comparisons between nations, Villavicencio Calzadilla and Mauger (2018) developed a study on renewable energy projects in Chile, India, Kenya and Mexico, all developing nations. They made some recommendations for these countries to achieve their energy targets, such as: (a) facility location and community-based development; (b) environmental and social impact assessment provided by energy ventures and; c) collaborative governance, public participation and transparency.

Considering the context of public policies related to energetic sector of developing countries, Baldwin et al. (2019) and Ureta (2017) argue that there are many incentives from the global community for these countries to adopt renewable energy policies towards producing and developing of an energy increasingly clear. These authors highlight that little is known about the factors that drive the adoption of renewable energy policies by developing countries. Contributing to this theme, Bhamidipati et al. (2019) state that the definition and consolidation of public policies in the energy sector play an important role in achieving sustainable targets focused on encouraging investments in renewable energy generation, otherwise, the authors point out that there is still a lack of understanding in the energy sector about how policy transfer happens between countries.

Marques et al. (2019) also emphasize the importance of designing energy policies, especially those focused on renewable energy. The authors argue that these actions are crucial to addressing the major challenges of combining economic growth and sustainable development. Therefore, governments and policy makers around the world must recognize the important role that the energy context plays in reducing poverty and reducing the negative environmental impact on the ecosystem.

In this sense, Erdiwansyah et al. (2019) developed a study to analyze government policies that promote the use of renewable sources in clean energy generation. However, there are barriers to policy definition and consolidation in the sector. Among these barriers, the following stand out: public awareness, the definition of policies without considering market trends, the difficulty of governments and policy makers in clarifying to community the essential role of the energy sector for sustainable development and the lack of an appropriate mechanism for implementing these policies (Cox et al., 2019; Erdiwansyah et al., 2019). Additionally, Herrera et al. (2019) argue that despite consensus on the urgency of consolidating solid public policies in the energy field, misguided approaches to renewable energy infrastructure result in delayed adoption of clean energy sources.

Costantini et al. (2018) emphasize that the implementation of a robust set of public policies in the energy sector, in addition to promoting sustainable development, also has a direct impact on a country's economic growth, especially through job creation. A recent example is the actions taken in Chile. The Chilean government has been developing and implementing policies in its energy sector aimed at minimizing climate change through the transition to a more sustainable energy system. For this, the country has been investing in actions to reduce emissions and consequently reaching its sustainable goals, which are regulated by government studies (Simsek et al., 2019).

In the same line of reasoning, Nigeria has adopted various programs and policies in an attempt to make its energy system efficient. However, due to underutilized resources and irrelevant public policies, the country has been facing serious problems in achieving this goal. Studies show the need for a more coordinated restructuring of actions in the country, achieving specific and timely goals, increasing political commitment, defining and designing consistent policies, research and activities for energy sector development, social awareness and greater public engagement, in order to move the country towards sustainable development (Gungah et al., 2019). 
Analyzing the research mentioned above on sustainable development objectives and public policies in the energy sector, it is possible to verify the variety of concepts and the different objectives they present. This demonstrates the literature's efforts to broaden the debate about this context. It is also possible to notice the focus on the following themes: contributions of the energy sector to reach the SDGs, evaluation of the effectiveness of public policies in the renewable energy context, barriers to the definition and implementation of policies in this field and the lack of approaches that enhance the insertion and consolidation of proposed policies for the energy sector. However, no studies were found that aimed to analyze the Brazilian contributions towards the achievement of the goals defined in the UN SDG 7. Thus, this research aims to fill this research gap.

\section{Methodological procedures}

To conduct of this study, the following steps were developed: a) a theoretical background on energy efficiency and sustainable development objectives, with a special focus on the seventh objective; b) a survey conducted with 42 energy planning specialists who know the Brazilian reality; c) a data analysis using means and a ranking of the analysed items via TOPSIS technique; $d$ ) the establishment of conclusions about the findings.

The theoretical background was conducted in the scientific bases: Science Direct, Taylor \& Francis, Emerald Insight and Wiley, in order to find articles that would allow the theoretical foundation. Combinations of the following terms were used: "Sustainable development goals", "Sustainable development goals number 7", "Brazil", "Renewable energy" and "Sustainable energy".

The targets set by the UN for the 7th Sustainable Development Goal - "Ensure access to affordable, reliable, sustainable and modern energy for all" - served as the basis for structuring the research instrument used in this survey. The authors of this article chose to separate some of them into specific topics without loss of content, making respondents' understanding more pragmatic. The result of this separation is presented in Chart 1 .

Chart 1. Targets of the 7th Goal separated into specific topics to develop the questionnaire. Source: Authors, based on UN (2015).

\begin{tabular}{|l|}
\hline Achieve universal access to energy services (M1) \\
\hline Ensure reliable energy access (M2) \\
\hline Ensure access to modern energy technologies (M3) \\
\hline Ensuring affordable energy access (M4) \\
\hline Increase energy generation from renewable sources (M5) \\
\hline Substantially increase energy efficiency (M6) \\
\hline $\begin{array}{l}\text { Develop international partnerships in search of research and technologies for energy with lower social and } \\
\text { environmental impacts (M7) }\end{array}$ \\
\hline $\begin{array}{l}\text { Increase investment in infrastructure for energy generation with lower social and environmental impacts } \\
\text { (M8) }\end{array}$ \\
\hline Increase investment in research for energy generation with lower social and environmental impacts (M9) \\
\hline $\begin{array}{l}\text { Assist other countries in modern and sustainable energy generation, with improvements in their } \\
\text { infrastructure and technologies (M10) }\end{array}$ \\
\hline
\end{tabular}

For each item listed in Chart 1, the experts pointed out through an evolutionary scale from 0 to 10 how much they consider that Brazil has been developing activities to achieve it. For a better understanding of how respondents should rate their scores, explanatory bands were suggested, as shown in Chart 2. It is important to highlight that the two grades for 5 of the 6 bands was intended to allow fine adjustment of the response by the experts.

Chart 2. Grade bands used in the questionnaire (Source: Authors) 
Grades 3 or $4=$ Brazil has been conducting some actions towards the target, in a simple and punctual manner;

Grades 5 or $6=$ Brazil has been conducting actions towards the target, in a planned manner, but with ample possibilities for improvements in results

Grades 7 or $8=$ Brazil is developing planned activities and has achieved satisfactory results through individual efforts, but not on a national scale

Grades 9 or $10=$ Brazil is developing planned activities and has obtained satisfactory results on a national scale.

The structured research instrument and other project-related information were submitted to a Research Ethics Committee and approved for data collection. It is important to mention that in Brazil research involving human beings, even in opinion, needs to be appreciated by an ethics committee. This procedure is established by resolution 466/2012.

After this approval, data collection began with energy planning experts. An invitation was sent via email and the questionnaire was available to respondents on the Google Forms platform for a period of three months. The invitation via e-mail was sent to 197 experts and 42 of them answered the questionnaire, thus obtaining a return rate of $21.31 \%$. The questionnaire was answered by researchers $(26.19 \%)$, teachers $(23.80 \%)$, consultants $(2.38 \%)$ and directors, coordinators and engineers of energy companies (47.61\%). Among the respondents, $26.19 \%$ have more than twenty years of experience, $30.95 \%$ have between ten and twenty years of experience and $42.85 \%$ have less than 10 years of experience.

With the database obtained from the survey, the data analysis was performed through the averages attributed by the experts' groups, divided according to years of professional experience, and comparative ordering via multicriteria decision technique TOPSIS, following the considerations proposed by Singh et al. (2016). According to these authors, TOPSIS allows the ranking of alternatives considering different analysis criteria. These criteria may have different weights and, consequently, may denote varying degrees of importance, assisting in the foundation and efficiency in decision making. The authors of this paper analysing other applications of the TOPSIS technique in research attributed different weights to expert responses considering their experience time. The weights given were: $50 \%$ for the group with over 20 years of experience, $30 \%$ for the group with experience between 10 to 20 years and $20 \%$ for the group with less than 10 years of experience.

Comparative ordering via TOPSIS can be obtained by seven steps. In the first one, we must structure a matrix D with elements $\left(x_{i j}\right)$, where (i) refers to the alternatives and (j) refers to the analysis criteria. In the case of this research, the alternatives corresponded to the 10 targets presented in Chart 1 and the criteria corresponded to the averages assigned by each group of respondents. The mathematical representation of matrix D is shown in Chart 3 (Equation 1). In the second step, matrix D is normalized by Equation 2, resulting in a matrix called R matrix (Equation 3). Both Equation 2 and Equation 3 can be seen in Chart 3.

The third step is to weigh the values of Matrix $\mathrm{R}$ using Equation 4 to obtain Matrix $\mathrm{V}$ (see Chart 3$)$. Then the positive $\left(\mathrm{v}_{\mathrm{j}}^{+}\right)$and negative $\left(\mathrm{v}_{\mathrm{j}}{ }^{-}\right)$ideal solutions are determined, characterizing the fourth step. Positive ideal solution $\left(\mathrm{v}_{\mathrm{j}}^{+}\right)$and negative ideal solution $\left(\mathrm{v}_{\mathrm{j}}{ }^{-}\right)$ are the maximum and minimum values respectively existing in the Matrix $\mathrm{V}$ for each criterion analysed.

This was done to perform the fifth step, in which the positive and negative Euclidean distances of each alternative were calculated. For this, the Equations 6 and 7 presented in Chart 3 were used. Finally, having the Euclidean distance values, it was possible to calculate the $\mathrm{C}_{\mathrm{i}}{ }^{*}$ indicator and, through it, to rank the 10 targets analysed in the survey (step 6), according to the perception of energy planning experts in Brazil. It is noteworthy that the values of $\mathrm{C}_{\mathrm{i}}{ }^{*}$ must be between 0 and 1 . The calculation of the indicator $\mathrm{C}_{\mathrm{i}}{ }^{*}$ was made through Equation 8 presented in Chart 3.

Chart 3. Equations used in the TOPSIS technique (Singh et al., 2016) 


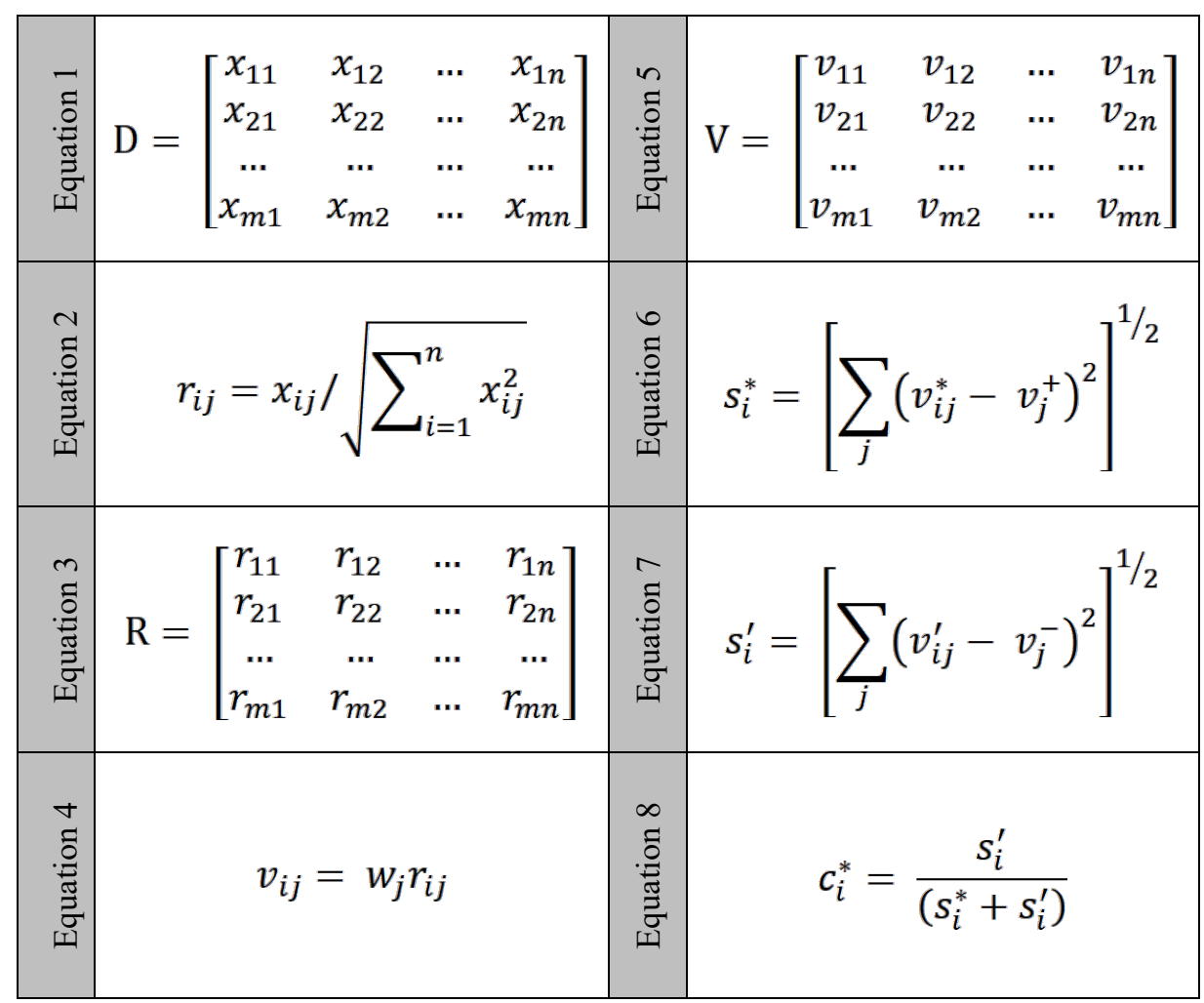

\section{Results and associated discussions}

This section presents the results and discussions of this research. Initially, Figure 1 shows the averages assigned by the specialists for each of the goals mentioned in Table 1 . The presentation of the averages was in terms of the participants' experience, since this division will be used in TOPSIS calculations.

Figure 1. Averages assigned to each target as a function of respondents' experience (Source:

\section{Authors)}

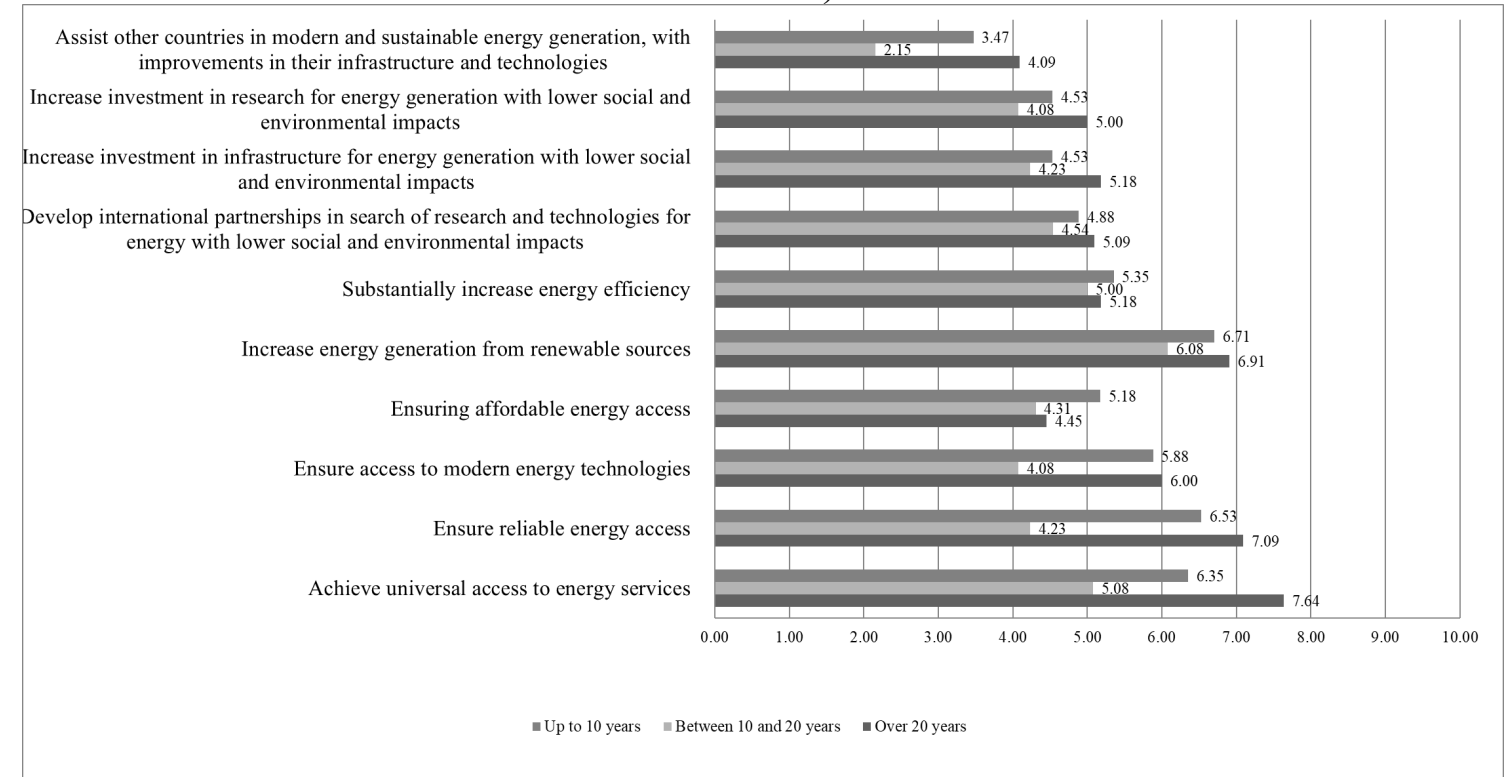

Analysing the averages obtained from the answers of the experts with the longest experience in the area of energy planning (over 20 years), and based on the scale from 0 to 10 presented in section 3 , it can be observed that in two of the ten targets analysed Brazil has been conducting some actions in a simple and punctual manner. These targets are: "Assist 
other countries in modern and sustainable energy generation, with improvements in their infrastructure and technologies" and "Ensuring affordable energy access". Another point that should be highlighted is the six targets, according to this first group, in which Brazil has been carrying out actions, in a planned manner, but with ample possibilities for improvement in results, namely: "Increase investment in research for energy generation with lower social and environmental impacts", "Increase investment in infrastructure for energy generation with lower social and environmental impacts", "Develop international partnerships in search of research and technologies for energy with lower social and environmental impacts"; "Substantially increase energy efficiency"; "Increase energy generation from renewable sources" and "Ensure access to modern energy technologies". In the opinion of the most experienced experts, the targets of "Ensure reliable energy access" and "Achieve universal access to energy services" are those in which Brazil is conducting planned activities, achieving satisfactory results through individual efforts, however not on a national scale. Considering these results, it worth to highlight that energy planning plays an indispensable role in policy formulation and nations development (Debnath and Mourshed, 2018).

Considering the averages from the opinion of experts who have between 10 and 20 years of experience in the area of energy planning, it is possible to realize that the targets considered more advanced are: "Increase energy generation from renewable sources" and "Achieve universal access to energy services". In both targets, in the opinion of these experts Brazil carries out actions in a planned manner, but with ample possibilities for improvement. On the other hand, the goals in which Brazil needs to improve considerably are: "Assist other countries in modern and sustainable energy generation, with improvements in their infrastructure and technologies", "Increase investment in research for power generation with lower social and environmental impacts" and "Ensure access to modern energy technologies". According to Sheng and Shi (2013), the integration among countries to supply the energy market is an important aspect of energy scenario, as integrated countries are more likely to reduce their income disparities, achieving egalitarian growth through economic consolidation. Another important point is regarding investments in research aiming at sustainable energy generation to guarantee access to modern technologies in the energy sector.

Still analysing Figure 1, but considering the averages assigned by the specialists with up to 10 years of experience, it can be observed that in the opinion of these professionals, the targets in which Brazil has the greatest advance are: "Increase energy generation from renewable sources" and "Ensure reliable energy access"; For specialists, in both goals Brazil has been carrying out actions in a planned manner, but with ample possibilities for improvements in the results achieved. In contrast, the target that presents few actions to achieve sustainable goals is to "Assist other countries in modern and sustainable energy generation, with improvements in their infrastructure and technologies". For these specialists, Brazil has not been acting in favour of this target, however there is an initial discussion about the subject. For Harjanne and Korhonen (2019), Lozano and Reid (2018) and Lior et al. (2018), renewable energy generation is a key factor in solving the global climate challenge, ensuring reliable access to energy.

It worth to highlight that Matrix D, represented by Equation 1 was removed of the results, since Figure 1 shows the data from this matrix. From the analysis of Figure 1, we proceeded to the ordering of targets related to SDG 7 via TOPSIS. It is noteworthy that the data collected through the survey were divided into three different groups, considering the time of the respondents' experience. Group 1 is composed by respondents with over 20 years of experience; in Group 2, the respondents have between 10 and 20 years of experience and Group 3 was for respondents with up to 10 years of experience. Based on the averages presented in Figure 1 for each group, the values were normalized using Equation 1 presented in section 3, resulting in Matrix R, presented in Table 1. 
Table 1. Matrix R with normalized values. Source: Authors.

\begin{tabular}{cccc}
\hline Code & rij (over 20 years) & rij (between 10 and 20 years) & rij (up to 10 years) \\
\hline M_1 & 0.42 & 0.36 & 0.37 \\
M_2 & 0.39 & 0.30 & 0.38 \\
M_3 & 0.33 & 0.29 & 0.34 \\
M_4 & 0.24 & 0.30 & 0.30 \\
M_5 & 0.38 & 0.43 & 0.39 \\
M_6 & 0.28 & 0.35 & 0.31 \\
M_7 & 0.28 & 0.32 & 0.28 \\
M_8 & 0.28 & 0.30 & 0.26 \\
M_9 & 0.27 & 0.29 & 0.26 \\
M_10 & 0.22 & 0.15 & 0.20 \\
\hline
\end{tabular}

Subsequently, weights were assigned to each group of respondents according to the information presented in section 2 of this article: experts with more than 20 years of experience received $50 \%$ weight, experts with 10 to 20 years of experience received $30 \%$ weight and experts with up to 10 years of experience received a weight of $20 \%$. Using this procedure, it was possible to obtain Matrix $\mathrm{V}$ as presented in Table 2.

Table 2. Matrix V with weighted values. Source: Authors.

\begin{tabular}{cccc}
\hline Code & rij (over 20 years) $\mathbf{0 . 5 0}^{\mathbf{0}}$ & rij (between $\mathbf{1 0}$ and 20 years)*0.30 & rij (up to 10 years)*0.20 \\
\hline M_1 & 0.21 & 0.11 & 0.07 \\
M_2 & 0.19 & 0.09 & 0.08 \\
M_3 & 0.16 & 0.09 & 0.07 \\
M_4 & 0.12 & 0.09 & 0.06 \\
M_5 & 0.19 & 0.13 & 0.08 \\
M_6 & 0.14 & 0.11 & 0.06 \\
M_7 & 0.14 & 0.10 & 0.06 \\
M_8 & 0.14 & 0.09 & 0.05 \\
M_9 & 0.14 & 0.09 & 0.05 \\
M_10 & 0.11 & 0.05 & 0.04 \\
\hline
\end{tabular}

Following the procedure, Table 3 presents the positive ideal solution and the negative ideal solution. This information is required to calculate the values in Table 4, which correspond to the Euclidean distances of the positive and negative ideal solution. Using Equation 8 presented in section 3 of this article, it was possible to calculate the coefficients $\mathrm{C}_{\mathrm{i}}{ }^{*}$ by which the ordering of the targets will be performed. These coefficients are also presented in Table 4.

Table 3. Positive ideal solution and negative ideal solution for criteria access. Source: Authors.

\begin{tabular}{cccc}
\hline Solution criteria & Over 20 years & Between 10 and 20 years & Up to 10 years \\
\hline Positive ideal solution $(\mathbf{v j}+)$ & 0.21 & 0.13 & 0.08 \\
Negative ideal solution $(\mathbf{v j}-)$ & 0.11 & 0.05 & 0.04 \\
\hline
\end{tabular}

Table 4. Positive ideal solution distance negative ideal solution distance, and coefficient $\mathrm{Ci}^{*}$. Source: Authors.

\begin{tabular}{cccc}
\hline Code & $\begin{array}{c}\text { Distances from the positive ideal } \\
\text { solution (Si+) }\end{array}$ & $\begin{array}{c}\text { Distances from the } \\
\text { negative ideal solution (Si-) }\end{array}$ & $\begin{array}{c}\text { Coefficients } \\
(\mathbf{C i})\end{array}$ \\
\hline M_1 & 0.02 & 0.12 & 0.85 \\
M_2 & 0.04 & 0.10 & 0.70 \\
M_3 & 0.06 & 0.07 & 0.54 \\
M_4 & 0.10 & 0.05 & 0.34 \\
M_5 & 0.02 & 0.12 & 0.86 \\
M_6 & 0.07 & 0.07 & 0.49 \\
M_7 & 0.08 & 0.06 & 0.43 \\
M_8 & 0.08 & 0.05 & 0.40 \\
M_9 & 0.09 & 0.05 & 0.36 \\
\hline
\end{tabular}




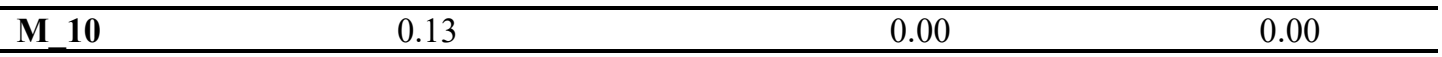

Finally, ranking the values of the coefficient $\mathrm{Ci} *$ obtained, it was obtained a comparative ordering of targets in terms of those most applied to the Brazilian reality. Table 5 presents the results of this ordering.

Table 5. Ranking of the items. Source: Authors.

\begin{tabular}{|c|c|c|c|}
\hline Position & $\left(\mathrm{Ci}^{*}\right)$ & Code & Items \\
\hline $1^{\circ}$ & 0.857174016 & M 5 & Increase energy generation from renewable sources \\
\hline $\mathbf{2}^{\mathbf{o}}$ & 0.847505037 & M_1 & Achieve universal access to energy services \\
\hline $3^{\circ}$ & 0.704136462 & M_2 & Ensure reliable energy access \\
\hline $4^{0}$ & 0.535614808 & M_3 & Ensure access to modern energy technologies \\
\hline $5^{\circ}$ & 0.493280025 & M_6 & Substantially increase energy efficiency \\
\hline $6^{\circ}$ & 0.42818894 & M_7 & $\begin{array}{l}\text { Develop international partnerships in search of research and } \\
\text { technologies for energy with lower social and environmental } \\
\text { impacts }\end{array}$ \\
\hline $7^{\circ}$ & 0.400304401 & M_8 & $\begin{array}{c}\text { Increase investment in infrastructure for energy generation with } \\
\text { lower social and environmental impacts }\end{array}$ \\
\hline $8^{\circ}$ & 0.360549952 & M_9 & $\begin{array}{l}\text { Increase investment in research for energy generation with } \\
\text { lower social and environmental impacts }\end{array}$ \\
\hline $9^{\circ}$ & 0.344681154 & M_4 & Ensuring affordable energy access \\
\hline $10^{\circ}$ & 0.000000000 & M_10 & $\begin{array}{l}\text { Assist other countries in modern and sustainable energy } \\
\text { generation, with improvements in their infrastructure and } \\
\text { technologies }\end{array}$ \\
\hline
\end{tabular}

Once the results are presented, the discussions should be presented. According to the averages attributed by the respondents of each group and presented in Figure 1, it is possible to realize that although some targets have median values, in general there is still much to do in terms of actions related to the Brazilian energy planning, in order to contribute to a more sustainable future. In this sense, it is necessary to develop planned activities to achieve satisfactory and consolidated results on a national scale. Viviana and Castillo (2019) corroborate this point, emphasizing that energy planning is characterized as an important element in the sustainable development of a nation.

The application of the TOPSIS technique allowed to order comparatively studied targets. The first three targets listed by TOPSIS, "Increase energy generation from renewable sources", "Achieve universal access to energy services" and "Ensure reliable energy access", in the opinion of experts, are the most contributing to Brazil achieving the SDG 7, placing the country on the path to ensure affordable and clean energy for all. According to Guerra et al. (2015), Brazilian energy matrix characterizes Brazil as a world leader in electricity generation from renewable sources, enhancing the reach of access to energy services.

The targets classified as intermediate in the ranking, according to the experts, are characterized by the accomplishment of some actions in favour these targets, but in a simple and punctual manner, with no previous planning to reach solid results. In this sense, it is emphasized that investment in modern energy access technologies, enhancement of energy efficiency, international partnerships and increased investment in energy infrastructure are crucial factors for achieving SDG 7. Thus, Brazilian politicians can use these findings to direct policies related to energy planning and execution.

Finally, the goal that is less developed compared to the others corresponds to "Assist other countries in modern and sustainable energy generation, with improvements in their infrastructure and technologies". Assisting other countries in this objective is characterized as an important role in international relations among economies, providing equal development (Sheng and Shi, 2013).

\section{Conclusion and Policy Implications}


This article aimed to evaluate, according to expert's opinion, how Brazil has been acting in favour of these activities. Although the study is exploratory and based in a sample, the expertise level of respondents contributes to enhance the results and provides interesting insights. From the results presented, it can be concluded that the proposed objective for this research was achieved, since it was possible to understand how much Brazil has been developing activities in favour of SDG 7. A set of 10 targets were used to develop a questionnaire for a survey with 42 energy planning experts in Brazil. These experts were allocated into groups according to their years of professional experience. On average, it was observed that for most of the targets considered and analysed in this study, Brazil has been developing some actions in a simple and punctual manner, needing to move considerably towards developing more planned activities; with this, satisfactory and consolidated results are expected on a national scale. Comparative ordering via TOPSIS highlighted three targets in which Brazil is most advanced: "Increase energy generation from renewable sources", "Achieve universal access to energy services" and "Ensure reliable energy access" and a target in which there are great potential for improvement: "Assist other countries in modern and sustainable energy generation, with improvements in their infrastructure and technologies".

The Brazilian energy matrix is largely recognized as clean and diversified (de Melo et al., 2016; IEA, 2018; Pao and Fu, 2013; Pischke et al., 2019). However, when the targets from SDG 7 are considered, it is possible to verify that there are important issues to focus. The target in the last position shows that Brazil still have a long path to cross for $7^{\text {th }}$ goal, since a successful insertion of sustainability issues must be achieved globally. Additionally, the target "Ensuring affordable energy access" in the second worst position is also alarming. Brazil is a developing country with large problems of income inequality (Medeiros and Souza, 2014). Thus, Brazilian government must consider this a major issue to be addressed. Although essential, the generation of energy from renewable sources and the universal access to energy services and the reliability of energy access are not enough. All the targets must be considered for a satisfactory achievement of the considered goal.

These findings provide an overview of Brazilian current scenario and can be used by Brazilian government to improve the least focused targets through the establishment of policies that focus on them and thus provide greater effectiveness in Brazil's search for the 7 SDG. We also highlight the importance of the findings of this article, both for market professionals working in the area of energy planning and for researchers interested in the subject. Professionals working in the area can use the findings presented here to assist in the planning of sustainable actions in the energy context. Researchers, in turn, can use the findings presented here to develop new technologies, tools and models to meet the development needs of the global energy sector. Additionally, this study can be replicated for different countries in order to direct the policies of them.

Finally, regarding the limitations of this study it is important to mention the sample size of 42 respondents. However, it is noteworthy that these respondents have experiences in the area of energy planning in the Brazilian context and are qualified. The authors of this article emphasize once again the exploratory nature of the research and believe that the discussions presented here can greatly contribute to broadening the debates about the actions that Brazil has been developing to achieve the UN SDG 7.

\section{References}

Arias-Gaviria, J., Carvajal-Quintero, S.X., Arango-Aramburo, S., 2019. Understanding dynamics and policy for renewable energy diffusion in Colombia. Renew. Energy 139, 1111-1119. https://doi.org/10.1016/j.renene.2019.02.138

Baldwin, E., Carley, S., Nicholson-Crotty, S., 2019. Why do countries emulate each others' 
policies? A global study of renewable energy policy diffusion. World Dev. 120, 29-45. https://doi.org/10.1016/j.worlddev.2019.03.012

Barata, J., Quelhas, O., Costa, H., Gutierrez, R., de Jesus Lameira, V., Meiriño, M., 2014. Multi-Criteria Indicator for Sustainability Rating in Suppliers of the Oil and Gas Industries in Brazil. Sustainability 6, 1107-1128. https://doi.org/10.3390/su6031107

Barthélemy, E.J., Park, K.B., Johnson, W., 2018. Neurosurgery and Sustainable Development Goals. World Neurosurg. 120, 143-152. https://doi.org/10.1016/j.wneu.2018.08.070

Basaran, S.T., Dogru, A.O., Balcik, F.B., Ulugtekin, N.N., Goksel, C., Sozen, S., 2015. Assessment of renewable energy potential and policy in Turkey - Toward the acquisition period in European Union. Environ. Sci. Policy 46, 82-94. https://doi.org/10.1016/j.envsci.2014.08.016

Bebbington, J., Unerman, J., 2018. Achieving the United Nations Sustainable Development Goals. Accounting, Audit. Account. J. 31, 2-24. https://doi.org/10.1108/AAAJ-05-20172929

Bhamidipati, P.L., Haselip, J., Elmer Hansen, U., 2019. How do energy policies accelerate sustainable transitions? Unpacking the policy transfer process in the case of GETFiT Uganda. Energy Policy 132, 1320-1332. https://doi.org/10.1016/j.enpol.2019.05.053

Borges, M.L., Anholon, R., Cooper Ordoñez, R.E., Quelhas, O.L.G., Santa-Eulalia, L.., Leal Filho, W., 2018. Corporate Social Responsibility (CSR) practices developed by Brazilian companies: an exploratory study. Int. J. Sustain. Dev. World Ecol. 25, 509-517. https://doi.org/10.1080/13504509.2017.1416700

Carstens, D.D. dos S., Cunha, S.K. da, 2019. Challenges and opportunities for the growth of solar photovoltaic energy in Brazil. Energy Policy 125, 396-404. https://doi.org/10.1016/j.enpol.2018.10.063

Cernev, T., Fenner, R., 2020. The importance of achieving foundational Sustainable Development Goals in reducing global risk. Futures 115, 102492. https://doi.org/10.1016/j.futures.2019.102492

Chams, N., García-Blandón, J., 2019. On the importance of sustainable human resource management for the adoption of sustainable development goals. Resour. Conserv. Recycl. 141, 109-122. https://doi.org/10.1016/j.resconrec.2018.10.006

Costantini, V., Crespi, F., Paglialunga, E., 2018. The employment impact of private and public actions for energy efficiency: Evidence from European industries. Energy Policy 119, 250-267. https://doi.org/10.1016/j.enpol.2018.04.035

Cox, E., Royston, S., Selby, J., 2019. From exports to exercise: How non-energy policies affect energy systems. Energy Res. Soc. Sci. 55, 179-188. https://doi.org/10.1016/j.erss.2019.05.016

Cozendey da Silva, H.N., Prata, D.M., Alves Lima, G.B., Zotes, L.P., Mattos, L.V., 2018. A techno-economic evaluation of the energy generation by proton exchange membrane fuel cell using biogas reforming. J. Clean. Prod. 200, 598-608. https://doi.org/10.1016/j.jclepro.2018.07.120

de Melo, C.A., Jannuzzi, G.D.M., Bajay, S.V., 2016. Nonconventional renewable energy governance in Brazil: Lessons to learn from the German experience. Renew. Sustain. Energy Rev. 61, 222-234. https://doi.org/10.1016/j.rser.2016.03.054

de Oliveira Neto, G.C., Ferreira Correia, J.M., Silva, P.C., de Oliveira Sanches, A.G., Lucato, W.C., 2019. Cleaner Production in the textile industry and its relationship to sustainable development goals. J. Clean. Prod. 228, 1514-1525. https://doi.org/10.1016/j.jclepro.2019.04.334

Debnath, K.B., Mourshed, M., 2018. Forecasting methods in energy planning models. Renew. Sustain. Energy Rev. 88, 297-325. https://doi.org/10.1016/j.rser.2018.02.002

Dranka, G.G., Ferreira, P., 2018. Planning for a renewable future in the Brazilian power 
system. Energy 164, 496-511. https://doi.org/10.1016/j.energy.2018.08.164

Erdiwansyah, Mamat, R., Sani, M.S.M., Sudhakar, K., 2019. Renewable energy in Southeast Asia: Policies and recommendations. Sci. Total Environ. 670, 1095-1102. https://doi.org/10.1016/j.scitotenv.2019.03.273

Few, S., Schmidt, O., Gambhir, A., 2019. Energy access through electricity storage: Insights from technology providers and market enablers. Energy Sustain. Dev. 48, 1-10. https://doi.org/10.1016/j.esd.2018.09.008

Filipović, S., Radovanović, M., Lior, N., 2019. What does the sharing economy mean for electric market transitions? A review with sustainability perspectives. Energy Res. Soc. Sci. 58, 101258. https://doi.org/10.1016/j.erss.2019.101258

Guerra, J.B.S.O.D.A., Dutra, L., Schwinden, N.B.C., Andrade, S.F. de, 2015. Future scenarios and trends in energy generation in brazil: supply and demand and mitigation forecasts. J. Clean. Prod. 103, 197-210. https://doi.org/10.1016/j.jclepro.2014.09.082

Güney, T., 2019. Renewable energy, non-renewable energy and sustainable development. Int. J. Sustain. Dev. World Ecol. 26, 389-397. https://doi.org/10.1080/13504509.2019.1595214

Gungah, A., Emodi, N.V., Dioha, M.O., 2019. Improving Nigeria's renewable energy policy design: A case study approach. Energy Policy 130, 89-100. https://doi.org/10.1016/j.enpol.2019.03.059

Harjanne, A., Korhonen, J.M., 2019. Abandoning the concept of renewable energy. Energy Policy 127, 330-340. https://doi.org/10.1016/j.enpol.2018.12.029

Hayat, F., Khan, A.A., Ashraf, M.A., 2019. Energy planning and sustainable development of Pakistan. Int. J. Energy Sect. Manag. 13, 24-44. https://doi.org/10.1108/IJESM-04-20180006

Herrera, M.M., Cosenz, F., Dyner, I., 2019. How to support energy policy coordination? Findings from the Brazilian wind industry. Electr. J. 32, 106636. https://doi.org/10.1016/j.tej.2019.106636

IEA, 2018. International Energy Agency. Electricity generation from renewables by source.

Jalali Sepehr, M., Haeri, A., Ghousi, R., 2019. A cross-country evaluation of energy efficiency from the sustainable development perspective. Int. J. Energy Sect. Manag. IJESM-03-2018-0005. https://doi.org/10.1108/IJESM-03-2018-0005

Jiménez-Aceituno, A., Peterson, G.D., Norström, A. V., Wong, G.Y., Downing, A.S., 2019. Local lens for SDG implementation: lessons from bottom-up approaches in Africa. Sustain. Sci. https://doi.org/10.1007/s11625-019-00746-0

Kveselis, V., Dzenajavičienė, E.F., Masaitis, S., 2017. Analysis of energy development sustainability: The example of the lithuanian district heating sector. Energy Policy 100, 227-236. https://doi.org/10.1016/j.enpol.2016.10.019

Leal Filho, W., Shiel, C., Paço, A., Mifsud, M., Ávila, L.V., Brandli, L.L., Molthan-Hill, P., Pace, P., Azeiteiro, U.M., Vargas, V.R., Caeiro, S., 2019. Sustainable Development Goals and sustainability teaching at universities: Falling behind or getting ahead of the pack? J. Clean. Prod. 232, 285-294. https://doi.org/10.1016/j.jclepro.2019.05.309

Lior, N., Radovanović, M., Filipović, S., 2018. Comparing sustainable development measurement based on different priorities: sustainable development goals, economics, and human well-being-Southeast Europe case. Sustain. Sci. 13, 973-1000. https://doi.org/10.1007/s11625-018-0557-2

Lozano, R., Reid, A., 2018. Socially responsible or reprehensible? Investors, electricity utility companies, and transformative change in Europe. Energy Res. Soc. Sci. 37, 37-43. https://doi.org/10.1016/j.erss.2017.09.018

Macellari, M., Gusmerotti, N.M., Frey, M., Testa, F., 2018. Embedding biodiversity and ecosystem services in corporate sustainability: A strategy to enable Sustainable 
Development Goals. Bus. Strateg. Dev. 1, 244-255. https://doi.org/10.1002/bsd2.34

Marques, A.C., Fuinhas, J.A., Pereira, D.S., 2019. The dynamics of the short and long-run effects of public policies supporting renewable energy: A comparative study of installed capacity and electricity generation. Econ. Anal. Policy 63, 188-206. https://doi.org/10.1016/j.eap.2019.06.004

Medeiros, M., Souza, P.H.G.F., 2014. THE STATE AND INCOME INEQUALITY IN BRAZIL, Institute for Applied Economic Research (Ipea).

Moyer, J.D., Bohl, D.K., 2019. Alternative pathways to human development: Assessing tradeoffs and synergies in achieving the Sustainable Development Goals. Futures 105, 199 210. https://doi.org/10.1016/j.futures.2018.10.007

Munro, P., van der Horst, G., Healy, S., 2017. Energy justice for all? Rethinking Sustainable Development Goal 7 through struggles over traditional energy practices in Sierra Leone. Energy Policy 105, 635-641. https://doi.org/10.1016/j.enpol.2017.01.038

Olawuyi, D., 2020. Sustainable development and the water-energy-food nexus: Legal challenges and emerging solutions. Environ. Sci. Policy 103, 1-9. https://doi.org/10.1016/j.envsci.2019.10.009

Pao, H.-T., Fu, H.-C., 2013. Renewable energy, non-renewable energy and economic growth in Brazil. Renew. Sustain. Energy Rev. 25, 381-392. https://doi.org/10.1016/j.rser.2013.05.004

Pischke, E.C., Solomon, B., Wellstead, A., Acevedo, A., Eastmond, A., De Oliveira, F., Coelho, S., Lucon, O., 2019. From Kyoto to Paris: Measuring renewable energy policy regimes in Argentina, Brazil, Canada, Mexico and the United States. Energy Res. Soc. Sci. 50, 82-91. https://doi.org/10.1016/j.erss.2018.11.010

Sahabmanesh, A., Saboohi, Y., 2017. Model of sustainable development of energy system, case of Hamedan. Energy Policy 104, 66-79. https://doi.org/10.1016/j.enpol.2017.01.039

Salvia, A.L., Leal Filho, W., Brandli, L.L., Griebeler, J.S., 2019. Assessing research trends related to Sustainable Development Goals: local and global issues. J. Clean. Prod. 208, 841-849. https://doi.org/10.1016/j.jclepro.2018.09.242

Sheng, Y., Shi, X., 2013. Energy market integration and equitable growth across countries. Appl. Energy 104, 319-325. https://doi.org/10.1016/j.apenergy.2012.10.043

Simsek, Y., Lorca, Á., Urmee, T., Bahri, P.A., Escobar, R., 2019. Review and assessment of energy policy developments in Chile. Energy Policy 127, 87-101. https://doi.org/10.1016/j.enpol.2018.11.058

Singh, R.K., Gupta, A., Kumar, A., Khan, T.A., 2016. Ranking of barriers for effective maintenance by using TOPSIS approach. J. Qual. Maint. Eng. 22, 18-34. https://doi.org/10.1108/JQME-02-2015-0009

The World Bank, 2019. GDP Ranking.

UN, 2019. Global indicator framework for the Sustainable Development Goals and targets of the 2030 Agenda for Sustainable Development [WWW Document]. URL https://unstats.un.org/sdgs/indicators/Global Indicator Framework after 2019 refinement_Eng.pdf (accessed 6.4.19).

UN, 2015. Sustainable Development Goals (SDGs) [WWW Document]. URL https://www.un.org/sustainabledevelopment/sustainable-development-goals/ (accessed 5.1.19).

Ureta, S., 2017. A very public mess: Problematizing the "participative turn" in energy policy in Chile. Energy Res. Soc. Sci. 29, 127-134. https://doi.org/10.1016/j.erss.2017.04.009

Villavicencio Calzadilla, P., Mauger, R., 2018. The UN's new sustainable development agenda and renewable energy: the challenge to reach SDG7 while achieving energy justice. J. Energy Nat. Resour. Law 36, 233-254. https://doi.org/10.1080/02646811.2017.1377951 
Viviana, M., Castillo, O.L., 2019. Colombian energy planning - Neither for energy, nor for Colombia. Energy Policy 129, 1132-1142. https://doi.org/10.1016/j.enpol.2019.03.025 